\title{
Prolonged Endothelin A Receptor Blockade Attenuates Chronic Pulmonary Hypertension in the Ovine Fetus
}

\author{
D. Dunbar Ivy, ${ }^{\star}$ Thomas A. Parker, ${ }^{\ddagger}$ James W. Ziegler, ${ }^{\star *}$ Henry L. Galan, John P. Kinsella, ${ }^{\ddagger}$ Rubin M. Tuder, \\ and Steven H. Abman $\$$ \\ $*$ Section of Cardiology, ${ }^{\ddagger}$ Section of Neonatology, ${ }^{\S}$ Section of Pulmonary Medicine and Critical Care, $\|$ Department of Pediatrics, Obstetrics \\ and Gynecology, and ${ }^{\mathbb{I}}$ Department of Pathology, Pediatric Heart Lung Center, University of Colorado School of Medicine \& The \\ Children's Hospital, Denver, Colorado 80218; and **Section of Cardiology, Department of Pediatrics, Brown University, Providence, \\ Rhode Island 02912
}

\begin{abstract}
Based on past studies of an experimental model of severe intrauterine pulmonary hypertension, we hypothesized that endothelin-1 (ET-1) contributes to high pulmonary vascular resistance (PVR), hypertensive lung structural changes, and right ventricular hypertrophy $(\mathrm{RVH})$ caused by prolonged closure of the ductus arteriosus. To test this hypothesis, we studied the effects of $B Q 123$, a selective $E_{\mathrm{A}}$ receptor antagonist, after ligation of the ductus arteriosus in utero. In 19 late gestation fetal lambs $(126 \pm 3 \mathrm{~d} ; 147 \mathrm{~d}$, term) we ligated the ductus arteriosus at surgery, and treated animals with either BQ $123(1 \mathrm{mg} / \mathrm{d})$ or vehicle (0.1\% DMSO, HTN) in the pulmonary artery for $8 \mathrm{~d}$. Chronic BQ 123 treatment attenuated the rise in mean pulmonary artery pressure (PAP) $8 \mathrm{~d}$ after ductus arteriosus ligation $(78 \pm 2$, HTN vs. $70 \pm 4 \mathrm{mmHg}$, BQ 123, $P<0.05)$. To study the effects of $\mathrm{ET}_{\mathrm{A}}$ blockade at birth, 15 animals were delivered by cesarean section and ventilated with $10 \%$ oxygen $\left(\mathrm{O}_{2}\right), 100 \% \mathrm{O}_{2}$ and inhaled nitric oxide (NO). Lambs treated with BQ 123 had lower PVR after delivery during ventilation with $10 \%$ $\mathrm{O}_{2}, 100 \% \mathrm{O}_{2}$, and inhaled NO (HTN vs. BQ $123, P<0.05$ for each intervention). Acute BQ 123 treatment $(2 \mathrm{mg} / 30$ min) lowered PVR in three HTN animals ventilated with $100 \% \mathrm{O}_{2}$ and inhaled NO $(P<0.05)$. Chronic BQ 123 treatment prevented the development of $\mathrm{RVH}$ as determined by the ratio of the right ventricle/left ventricle + septum $(0.79 \pm 0.03$, HTN vs. $0.57 \pm 0.06$, BQ $123, P<0.05)$ and attenuated the increase in wall thickness of small pulmonary arteries $(61 \pm 2, \mathrm{HTN}$ vs. $50 \pm 2 \%$, BQ $123, P<0.05)$. In summary, chronic intrauterine $\mathrm{ET}_{\mathrm{A}}$ receptor blockade decreased PAP in utero, decreased RVH and distal muscularization of small pulmonary arteries, and increased the fall in PVR at delivery. We conclude that $\mathrm{ET}_{\mathrm{A}}$ receptor stimulation contributes to the pathogenesis and pathophysiology of experimental perinatal pulmonary hypertension. (J. Clin. Invest. 1997. 99:1179-1186.) Key words: endothelin • pul-
\end{abstract}

Address correspondence to D. Dunbar Ivy, M.D., Department of Cardiology, Box B100, The Children's Hospital, 1056 E. 19th Ave., Denver, CO 80218. Phone: 303-861-6820; FAX: 303-837-2595; E-mail: dunbar.ivy@UCHSC.edu

Received for publication 14 October 1996 and accepted in revised form 26 December 1996.

J. Clin. Invest.

(C) The American Society for Clinical Investigation, Inc. 0021-9738/97/03/1179/08 \$2.00

Volume 99, Number 6, March 1997, 1179-1186 monary hypertension • nitric oxide • endothelin receptors • persistent pulmonary hypertension of the newborn • fetus • pulmonary circulation $\bullet$ BQ 123

\section{Introduction}

The clinical syndrome of persistent pulmonary hypertension of the newborn (PPHN $)^{1}$ is characterized by elevated pulmonary vascular resistance (PVR) resulting in right-to-left shunting across the foramen ovale and ductus arteriosus with severe hypoxemia (1). Although mechanisms contributing to PPHN are poorly understood, clinical and experimental studies suggest that chronic pulmonary hypertension in utero leads to failure of the normal transition at birth (1-4). Chronic intrauterine pulmonary hypertension due to ligation of the ductus arteriosus in fetal lambs causes marked elevation of intrauterine pulmonary artery pressure, right ventricular hypertrophy, hypertensive lung structural changes, as well as abnormal pulmonary vasoreactivity and the failure to achieve the normal decline in pulmonary resistance at birth (2-5). This experimental model of pulmonary hypertension is also characterized by attenuation of pulmonary vasodilation to small increases in fetal $\mathrm{Po}_{2}$ (2), and impairment of endothelium-dependent vasodilation to acetylcholine (6). Ligation of the ductus arteriosus in late-gestation fetal lambs has provided an experimental model for studying mechanisms contributing to structural and functional changes associated with perinatal pulmonary hypertension $(2$, $3,5,6)$.

Past studies of this experimental model of PPHN suggest that high PVR is partly due to structural changes and an imbalance in production or responsiveness to vasodilator and vasoconstrictor stimuli (2-6). Endothelium-dependent vasodilation and nitric oxide (NO) activity are impaired in the hypertensive fetal lung, whereas vasodilation to the cGMP agonists, atrial natriuretic peptide, and inhaled NO, remain intact (6). Endothelin-1 (ET-1) is a potent vasoactive peptide with mitogenic effects on vascular smooth muscle, and is produced primarily by the vascular endothelium in the normal lung circulation $(7$, 8). In the normal fetal lung, ET-1 is present, and contributes to high PVR (9-12). We have previously shown that chronic intrauterine pulmonary hypertension causes the loss of $\mathrm{ET}_{\mathrm{B}}{ }^{-}$ mediated vasodilation, progressive $\mathrm{ET}_{\mathrm{A}}$-mediated vasoconstriction, and increased lung ET-1 content (13). Little is

1. Abbreviations used in this paper: Ao, aorta; ET, endothelin; HTN, hypertension; LA, left atrium; LPA, left pulmonary artery; MPA, main pulmonary artery; NO, nitric oxide; PPHN, persistent pulmonary hypertension of the newborn; PAP, pulmonary artery pressure; PVR, pulmonary vascular resistance. 
known, however, about the role of ET-1 and its receptors in chronic pulmonary hypertension in the perinatal period.

We hypothesized that enhanced $\mathrm{ET}_{\mathrm{A}}$ receptor activity partially accounts for the in utero increases in PAP, the abnormal transition of the fetus with pulmonary hypertension after delivery, the right ventricular hypertrophy, and the smooth muscle lung changes in chronic pulmonary hypertension caused by ligation of the ductus arteriosus in fetal lambs. Therefore, we studied the role of the $\mathrm{ET}_{\mathrm{A}}$ receptor in the development of pulmonary hypertension in this model with the selective $\mathrm{ET}_{\mathrm{A}}$ antagonist BQ 123.

\section{Methods}

Surgical preparation and physiological measurements. All procedures and protocols were previously reviewed and approved by the Animal Care and Use Committee at the University of Colorado Health Sciences Center. 19 mixed breed (Columbia-Rambouillet, Santa Monica, CA) pregnant ewes between 125 and 129 days gestation (term $=$ $147 \mathrm{~d}$ ) were fasted $24 \mathrm{~h}$ before surgery. Ewes were sedated with intravenous pentobarbital sodium $(2-4 \mathrm{~g})$ and anesthetized with $1 \%$ tetracaine hydrochloride $(3 \mathrm{mg}$ ) by lumbar puncture. Ewes were kept sedated with pentobarbital but breathed spontaneously throughout the surgery. Penicillin $(500 \mathrm{mg})$ and streptomycin $(1 \mathrm{~g})$ were administered to the ewe at surgery. Under sterile conditions, the fetal lamb's left forelimb was delivered through a uterine incision. A skin incision was made under the left forelimb after local infiltration with lidocaine (2-3 $\mathrm{ml}, 1 \%$ solution). Polyvinyl catheters were advanced into the ascending aorta (Ao) and superior vena cava after insertion into the axillary artery and vein. A left axillary to sternal thoracotomy exposed the heart and great arteries. A catheter was inserted into the main pulmonary artery (MPA) by direct puncture through purse string sutures, as previously described (14). Catheters were guided into position with a 14- or 16-gauge intravenous placement unit (Angiocath; Travenol Laboratories, Deerfield, IL). Catheters were secured by tightening the purse string suture as the introducer was withdrawn. The MPA catheter was inserted between the ductus arteriosus and the pulmonic valve. The ductus arteriosus was partially ligated using umbilical tape (13). The thoracotomy incision was closed in layers. The uteroplacental circulation was kept intact and the fetus was gently placed in the uterus, with exposed surfaces bathed in warm towels. Ampicillin (500 $\mathrm{mg}$ ) was added to the amniotic cavity before closure of the hysterotomy. Ampicillin $(250 \mathrm{mg}$ ) was infused daily in the fetal vein and amniotic cavity during the first $3 \mathrm{~d}$ after surgery. The ewe was allowed to recover. The Ao, MPA, and amniotic cavity catheters were connected to a computer-driven pressure transducer and recorder (Biopac Systems, Santa Barbara, CA). Pressures were referenced to the amniotic cavity pressure. The pressure transducer was calibrated with a mercury column manometer. Heart rate was determined from phasic pulmonary blood flow tracings. Blood samples for $\mathrm{pH}, \mathrm{PCO}_{2}, \mathrm{PO}_{2}$, and hemoglobin $(\mathrm{Hb})$ were drawn from the Ao and measured at $39.5^{\circ} \mathrm{C}$ with a blood gas analyzer and hemoximeter (OSM-3; Radiometer, Copenhagen, Denmark).

Drug preparation. BQ 123 (Alexis Biochemicals, San Diego, CA) was dissolved in DMSO (1 mg in $300 \mu \mathrm{l})$. This solution was diluted in $24 \mathrm{ml}$ normal saline and directly infused into the MPA over $24 \mathrm{~h}$ at a rate of $1 \mathrm{ml} / \mathrm{h}$. DMSO ( $0.1 \%$ in normal saline) was infused at the same rate into control animals.

Protocol 1: Hemodynamic effects of prolonged BQ 123 treatment during chronic ductus arteriosus ligation $(n=19)$. To determine the hemodynamic effects of prolonged $\mathrm{ET}_{\mathrm{A}}$ receptor blockade after ductus arteriosus ligation, either BQ $123(1 \mathrm{mg} / \mathrm{d}, n=6)$ or the control solution $(0.1 \%$ DMSO, $n=13)$ was infused in the MPA by continuous infusion for $8 \mathrm{~d}$. Infusions were begun within $15 \mathrm{~min}$ of the completion of the ductus arteriosus ligation surgery. Measurements included daily pulmonary artery pressure (PAP), Pao, and heart rate measurements as well as arterial blood gas tensions drawn from the ascending Ao.

Protocol 2: Effects of prolonged BQ 123 treatment on the vasodilator response to birth-related stimuli and inhaled $N O$ after chronic intrauterine pulmonary hypertension $(n=15)$. To determine whether prolonged $\mathrm{ET}_{\mathrm{A}}$ receptor blockade improves pulmonary vasoreactivity and the decline in PVR at birth after ductus arteriosus ligation, we studied the hemodynamic and blood gas effects of prolonged BQ 123 treatment after cesarean section delivery and mechanical ventilation of the animals in protocol $1(n=5$, BQ $123 ; n=10$, hypertension $[\mathrm{HTN}])$. Animals underwent a second surgery at this time for placement of additional catheters and a flow transducer. These catheters and transducer, for the purpose of decreasing mortality in utero, were not placed at the original surgery. $8 \mathrm{~d}$ after ductus arteriosus ligation, the ewe was fasted for $24 \mathrm{~h}$ in preparation for study. On day 8, ewes were sedated with intravenous pentobarbital sodium $(2-4 \mathrm{~g})$ and anesthetized with $1 \%$ tetracaine hydrochloride $(3 \mathrm{mg})$ by lumbar puncture. Ewes were kept sedated with pentobaribital but breathed spontaneously throughout the surgery. Under aseptic conditions, the fetus was delivered through a uterine incision with the utero-placental circulation intact. A skin incision was made under the left forelimb after local infiltration with lidocaine (2-3 $\mathrm{ml}, 1 \%$ solution). A left axillary to sternal thoracotomy exposed the heart and great arteries. A catheter was inserted into the left atrium (LA) by direct puncture through purse string sutures, as described above. A 6.0-mm ultrasonic flow probe (Transonics Systems, Inc., Ithaca, NY) was placed around the left pulmonary artery (LPA) to measure blood flow to the left lung. BQ 123 or the control solution was continued in protocol 2 at the same flow rate as protocol 1 .

The flow transducer cables were attached to an internally calibrated flowmeter (Transonic) for continuous measurements of LPA flow. The absolute values of flows were determined from phasic blood flow signals obtained during baseline periods, as previously described $(15,16)$. A correction factor between end-diastolic flow and the internally calibrated zero point on the Transonic flow meter was added to the mean flow on the Transonics flow meter. The value obtained from this method correlates with previously determined measures of LPA flow in the late-gestation ovine fetal lung (15). Calculation of resistances are reported as left lung pulmonary vascular resistance $(\mathrm{PVR}, \mathrm{mmHg} / \mathrm{ml}$ per $\mathrm{min}=$ mean MPA pressure-mean LA pressure/LPA flow). Study measurements included PAP, Pao, Pla, LPA flow, and arterial blood gas tensions. Baseline measurements were recorded after $30 \mathrm{~min}$.

During the delivery study, pancuronium bromide $(0.3 \mathrm{mg}$, vena cava) was administered to the fetus, and the fetal head was delivered. A tracheostomy was performed, and a $5.0 \mathrm{~mm}$-ID endotracheal tube was inserted. Mechanical ventilation with $10 \% \mathrm{O}_{2} 90 \% \mathrm{~N}_{2}$ was initiated. The uterine incision was carefully extended to allow visualization of the thorax. Initial ventilator settings included a rate of 30 breaths per minute, peak inspiratory pressure of $30 \mathrm{~cm} \mathrm{H}_{2} \mathrm{O}$, positive end-expiratory pressure of $5 \mathrm{~cm} \mathrm{H}_{2} \mathrm{O}$, and inspiratory time of $0.8 \mathrm{~s}$. Peak inspiratory pressure was increased until chest wall motion could be observed with inspiration, to a maximum of $35 \mathrm{~cm} \mathrm{H}_{2} \mathrm{O}$. Rate was varied as necessary to maintain $\mathrm{PCO}_{2}$ close to $40 \mathrm{mmHg}$. Sodium bicarbonate $(3 \mathrm{meq})$ was given in the vena cava to correct a $\mathrm{pH}$ less than 7.2 if $\mathrm{PCO}_{2}$ was less than $50 \mathrm{mmHg}$. Animals were ventilated sequentially with $100 \% \mathrm{O}_{2}$ and $100 \% \mathrm{O}_{2}$ with 20 parts per million (ppm) inhaled NO. Inhaled NO was used to optimize vasodilation. The umbilical cord was then ligated, and the sequence of ventilation was repeated with $100 \% \mathrm{O}_{2}$ and $100 \% \mathrm{O}_{2}$ with inhaled NO (20 ppm). Studies were performed with the umbilical cord intact-and then with the umbilical cord ligated - to allow for stabilization of the lambs as previously reported (6).

To determine whether blockade of $\mathrm{ET}_{\mathrm{A}}$ receptor activity was sustained during treatment with BQ 123 , big-endothelin-1 $(1.5 \mu \mathrm{g} / \mathrm{min}$ for $10 \mathrm{~min}$ ), was infused in the pulmonary artery of three animals receiving prolonged BQ 123 treatment at the completion of the delivery study. Study measurements included PAP, Pao, Pla, LPA flow, and 
arterial blood gas tensions. In the late-gestation ovine fetla lung, infusion of big-endothelin-1 (the precursor to ET-1) in the pulmonary artery causes only hypertension without vasodilation (11). The hypertensive effect of big-ET-1 is blocked by the selective $\mathrm{ET}_{\mathrm{A}}$ receptor antagonist, BQ 123, suggesting that big-endothelin-1 causes stimulation of the $\mathrm{ET}_{\mathrm{A}}$ receptor (11).

Protocol 3: Hemodynamic effects of acute $B Q 123$ infusion after delivery. To determine residual $\mathrm{ET}_{\mathrm{A}}$-mediated vasoconstriction after delivery of lambs with chronic intrauterine pulmonary hypertension, we studied the acute response to BQ 123 (2 $\mathrm{mg}$ over $30 \mathrm{~min}$ ) in control hypertensive animals. BQ 123 was acutely infused in the MPA during ventilation with $100 \% \mathrm{O}_{2}$ and inhaled nitric oxide $(20 \mathrm{ppm})$ in three animals from protocol 2. Study measurements included PAP, Pao, Pla, LPA flow, and arterial blood gas tensions. The animals were killed with euthanasia solution.

Protocol 4: Assessment of cardiac hypertrophy $(n=15)$. To determine the effect of prolonged $\mathrm{ET}_{\mathrm{A}}$ receptor blockade with $\mathrm{BQ} 123$ on cardiac hypertrophy after ductus arteriosus ligation, cardiac weight of the right ventricle and left ventricle + septum was measured $(n=6$, BQ 123; $n=13, \mathrm{HTN})$. The ratio of right ventricle / left ventricle + septum was calculated.

Protocol 5: Morphometric evaluation of the effect of prolonged $E T_{A}$ receptor blockade with $B Q 123$ on lung histology $(n=10)$. To determine the effect of prolonged $\mathrm{ET}_{\mathrm{A}}$ receptor blockade with $\mathrm{BQ} 123$ on wall thickness of small pulmonary arteries after ductus arteriosus ligation, we performed morphometric evaluation of the lungs from animals killed in protocol $2(n=5$, BQ 123; $n=5$, HTN). Methods for examining lung histology and performing morphometric analysis included vascular perfusion of the pulmonary artery with $1 \%$ paraformaldehyde and tracheal fixation with $1 \%$ low temperature melting agarose (44). After fixation, thin longitudinal sections were cut, placed in paraformaldehyde, embedded in paraffin, and stained with hematoxylin and eosin. Morphometric analysis was performed by two blinded observers (S.H. Abman and R.M. Tuder) with a Zeiss Interactive Digital Analyzer System (Carl Zeiss Inc., Thornwood, NY). Pulmonary arteries less than $100 \mu \mathrm{m}$ were landmarked according to their associated airways (terminal bronchiole, respiratory bronchiole, alveolar duct); measurements included the wall thickness and vessel diameter of at least 20 consecutive pulmonary arteries per animal. The wall thickness (WT) of each artery was expressed as a percentage of the vessel diameter by the formula: $(2 \times$ medial wall thickness/external diameter) $\times 100$.

Data analysis. Data are presented as means \pm 1 SEM. Statistical analysis was performed with the Statview and Super ANOVA software packages (Abacus Concepts, Berkeley, CA). Comparisons were made using univariate repeated measures ANOVA by linear contrast analysis for protocols 1,2 , and 3. Comparisons were made using an unpaired $t$ test for protocols 4 and 5. $P<0.05$ was considered significant.

\section{Results}

Protocol 1: Hemodynamic effects of prolonged BQ 123 treatment during chronic ductus arteriosus ligation. Ductus arteriosus ligation causes progressive pulmonary hypertension as previously shown (13). Mean MPA pressure in the normal fetus at this gestational age is $43 \pm 4 \mathrm{mmHg}(13)$. After ductus arteriosus ligation, mean PAP rapidly increased to $65 \pm 2 \mathrm{mmHg}$ after the first day. Mean PAP progressively increased to $78 \pm 2$ $\mathrm{mmHg}$ after $8 \mathrm{~d}$ in untreated animals $(P<0.05$, Fig. 1$)$. Prolonged BQ 123 treatment did not change the early increase in PAP after ductus arteriosus ligation, but prevented progressive increases in PAP 8 days after ligation. PAP was lower in the animals treated with BQ 123 from 4 to $8 \mathrm{~d}$ after ductus arteriosus ligation. Mean Pao was lower in the BQ 123 group on day 8 (Fig. 1). Arterial blood gas tensions, hemoglobin, and heart rates were not different between the control and BQ 123

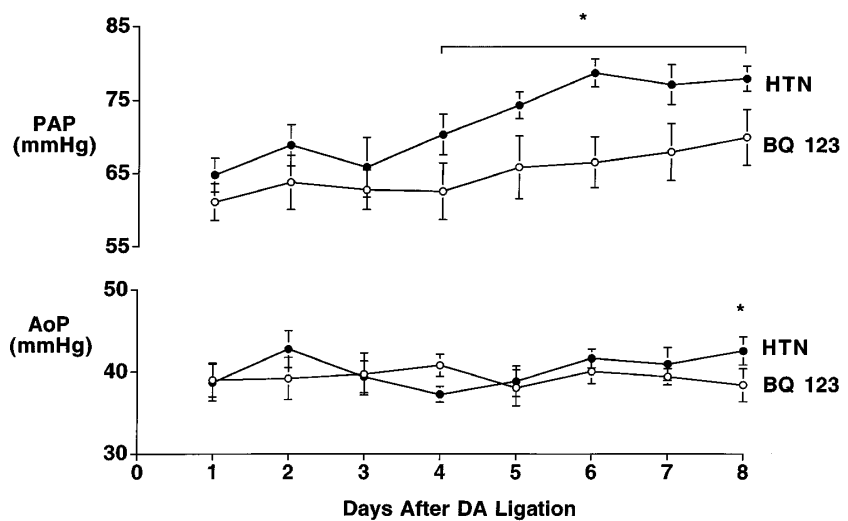

Figure 1. HTN vs. BQ 123. Hemodynamic effects of prolonged $\mathrm{ET}_{\mathrm{A}}$ receptor blockade with $\mathrm{BQ} 123$ (a selective $\mathrm{ET}_{\mathrm{A}}$ receptor antagonist) on intrauterine pressure after ductus arteriosus ligation. BQ 123 (1.0 $\mathrm{mg} /$ day) attenuated the progressive increase in pulmonary artery pressure $(P A P)$ in comparison with control $(H T N)$. Aortic pressure (AoP) was lower on day 8 in the BQ 123 group. ${ }^{*} P<0.05$.

treatment groups, however, $\mathrm{PO}_{2}$ and $\mathrm{H} / \mathrm{gb}$ were lower on day 8 than day 1 for both groups $(P<0.05$, Table I).

Protocol 2: Effects of prolonged BQ 123 treatment on the vasodilator response to birth-related stimuli and inhaled $N O$ after chronic intrauterine pulmonary hypertension. Chronic BQ 123 treatment lowered PVR and increased LPA flow at baseline prior to delivery (Fig. 2, Table II) During ventilation with the umbilical cord intact, (for low $\mathrm{O}_{2}[10 \%]$, high $\mathrm{O}_{2}[100 \%]$, $100 \% \mathrm{O}_{2}$ and inhaled NO), PVR remained lower at each intervention in the fetuses treated with prolonged BQ 123 treatment than in the control hypertensive group (Fig. 2). LPA flow was greater in the $\mathrm{BQ} 123$ group during ventilation with low $\mathrm{O}_{2}$, high $\mathrm{O}_{2}$, and high $\mathrm{O}_{2}$ and inhaled NO (Table II). PAP was lower in the BQ 123 group during ventilation with $100 \% \mathrm{O}_{2}$ and inhaled NO (Table II). Pao was higher in the control group only during ventilation with low $\mathrm{O}_{2}$. Measurement of $\mathrm{pH}$ was higher while measurement of $\mathrm{PCO}_{2}$ was lower in the BQ 123 group during ventilation with $100 \% \mathrm{O}_{2}$. Values for heart rate $(175 \pm 13,182 \pm 6 \mathrm{bpm}$; HTN vs. BQ 123$)$ and hemoglobin concentration $(7.1 \pm 0.4,6.4 \pm 0.5 \mathrm{~g} / \mathrm{dl}$; HTN vs. BQ 123$)$ were not different between the two groups at baseline or dur-

Table I. Effects of Daily Intrapulmonary BQ $123(1.0 \mathrm{mg} / \mathrm{d})$ or Control (HTN) Treatment on Arterial Blood Gas Tensions, Hemoglobin, and Heart Rate in Experimental Pulmonary Hypertension After Ductus Arteriosius Ligation

\begin{tabular}{lccccc}
\hline & \multicolumn{2}{c}{ Day 1 } & & \multicolumn{2}{c}{ Day 8 } \\
\cline { 2 - 3 } \cline { 5 - 6 } & HTN & BQ 123 & & HTN & BQ 123 \\
\hline $\mathrm{pH}$ (units) & $7.37 \pm 0.01$ & $7.34 \pm 0.01$ & & $7.33 \pm 0.02$ & $7.35 \pm 0.01$ \\
$\mathrm{PCO}_{2}(\mathrm{mmHg})$ & $52 \pm 2$ & $48 \pm 2$ & & $53 \pm 2$ & $51 \pm 1$ \\
$\mathrm{Po}_{2}(\mathrm{mmHg})$ & $17 \pm 1$ & $19 \pm 2$ & & $15 \pm 1^{*}$ & $15 \pm 1^{*}$ \\
$\mathrm{Hb}(\mathrm{g} / \mathrm{dl})$ & $7.5 \pm .22$ & $7.6 \pm .34$ & & $6.9 \pm .50^{*}$ & $6.7 \pm .20^{*}$ \\
$\mathrm{HR}(\mathrm{bpm})$ & $173 \pm 5$ & $175 \pm 4$ & & $166 \pm 4$ & $166 \pm 8$
\end{tabular}

Values are mean \pm SEM. Comparisons between HTN and BQ 123 values were made by repeated-measures ANOVA. ${ }^{*} P<0.05$ day 1 vs. day 8. Hb, hemoglobin; HR, heart rate, beats per min. 


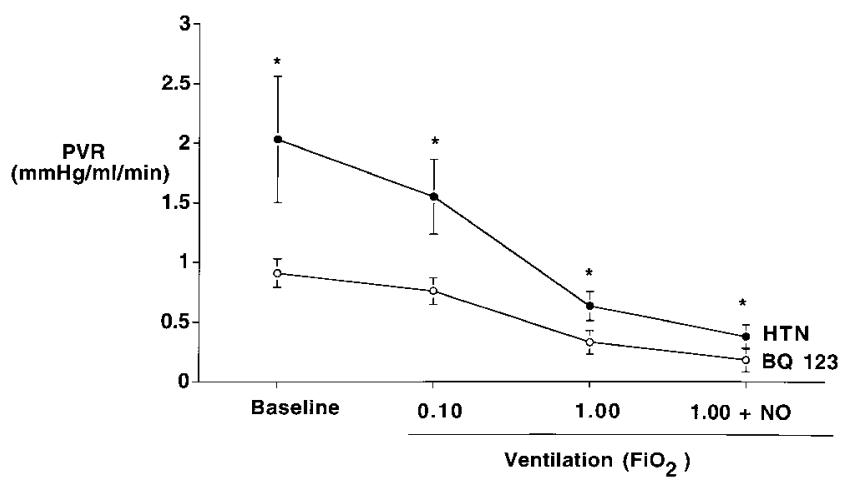

Figure 2. HTN vs. BQ 123. Hemodynamic effects of BQ 123 on pulmonary vascular resistance during acute delivery after ductus arteriosus ligation in the late-gestation fetal lamb. PVR was lower following BQ 123 treatment prior to ventilation (Baseline), and ventilation with low $\mathrm{FiO}_{2}(0.10)$, high $\mathrm{FiO}_{2}$ (1.00), and during ventilation with high $\mathrm{FiO}_{2}$ and $20 \mathrm{ppm}$ inhaled NO than control $(H T N) .{ }^{*} P<0.05$.

ing ventilation. At baseline, LA pressure was $3 \pm 2 \mathrm{mmHg}$ in the control group and $3 \pm 3 \mathrm{mmHg}$ in the BQ 123 group, and did not change with ventilation. The use of sodium bicarbonate was similar between the control group and the BQ 123 group ( $6 \pm 1$, HTN vs. $6 \pm 2$ meq, BQ 123).

After the umbilical cord was ligated, PVR was lower in the BQ 123 group during ventilation with $100 \mathrm{O}_{2}(0.63 \pm 0.12$ vs. $0.33 \pm 0.04 \mathrm{mmHg} / \mathrm{ml}$ per min, HTN vs. BQ $123, P<0.05)$ and $100 \% \mathrm{O}_{2}$ and $20 \mathrm{ppm}$ inhaled $\mathrm{NO}(0.38 \pm 0.06$ vs. $0.18 \pm 0.02$ $\mathrm{mmHg} / \mathrm{ml}$ per min, HTN vs. BQ $123, P<0.05)$. LPA flow was higher during ventilation with $100 \% \mathrm{O}_{2}$ and $100 \% \mathrm{O}_{2}$ with in-

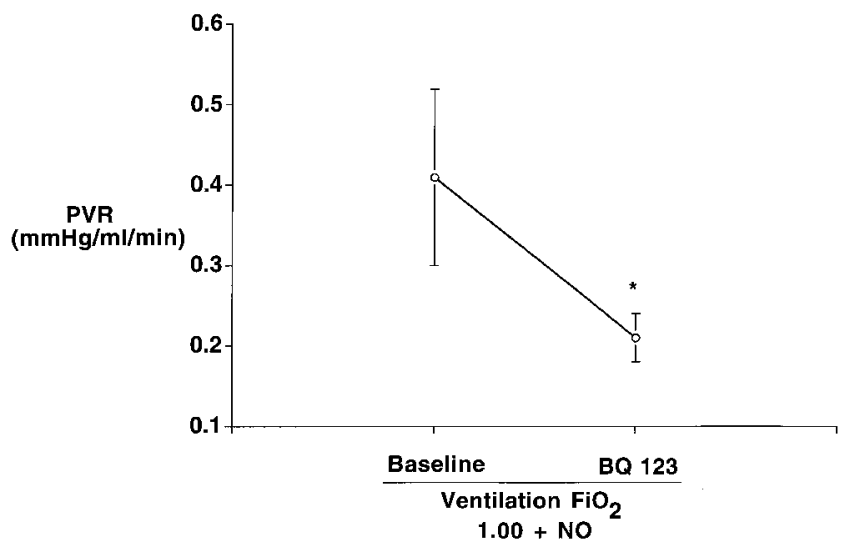

Figure 3. Baseline vs. BQ 123. Hemodynamic effects of acute BQ 123 treatment $(2 \mathrm{mg} / 30 \mathrm{~min})$ on pulmonary vascular resistance $(P V R)$ during acute delivery after ductus arteriosus ligation in the late-gestation fetal lamb. BQ 123 decreased PVR in control hypertensive animals during ventilation with $\mathrm{FiO}_{2} 1.00$ and 20 ppm inhaled NO. $* P<$ 0.05 .

haled NO, and PAP was lower in the BQ 123 group during ventilation with $100 \% \mathrm{O}_{2}$ and inhaled NO (Table II). Ao pressure was not different. Measurement of $\mathrm{pH}$ was higher during ventilation with $100 \% \mathrm{O}_{2}$ and inhaled $\mathrm{NO}$, while $\mathrm{PCO}_{2}$ was not different. During ventilation with $100 \% \mathrm{O}_{2}$ and $100 \% \mathrm{O}_{2}$ and inhaled $\mathrm{NO}, \mathrm{PO}_{2}$ was higher in the $\mathrm{BQ} 123$ group.

Following the delivery study, big-endothelin-1 $(1.5 \mu \mathrm{g} / \mathrm{min}$ for $10 \mathrm{~min}$ ) did not change PAP, Pao, Pla, LPA flow, or arterial blood gas tensions in three animals treated with prolonged

Table II. Changes in Hemodynamics, Arterial Blood Gas Tensions, and Hemoglobin During Mechanical Ventilation in Control or BQ 123 Treated Animals After In Utero Pulmonary Hypertension

\begin{tabular}{|c|c|c|c|c|c|c|}
\hline & \multicolumn{4}{|c|}{ Cord intact } & \multicolumn{2}{|c|}{ Cord tied } \\
\hline & Baseline & $10 \% \mathrm{O}_{2}$ & $100 \% \mathrm{O}_{2}$ & $\begin{array}{l}100 \% \mathrm{O}_{2}+ \\
\text { NO } 20 \mathrm{ppm}\end{array}$ & $100 \% \mathrm{O}_{2}$ & $\begin{array}{l}100 \% \mathrm{O}_{2}+ \\
\mathrm{NO} 20 \mathrm{ppm} \\
\end{array}$ \\
\hline \multicolumn{7}{|c|}{ LPA flow $(\mathrm{ml} / \mathrm{min})$} \\
\hline HTN & $48 \pm 9 *$ & $55 \pm 10^{*}$ & $89 \pm 14 *$ & $130 \pm 16^{*}$ & $104 \pm 20 *$ & $130 \pm 20 *$ \\
\hline BQ 123 & $80 \pm 8$ & $88 \pm 10$ & $168 \pm 11$ & $201 \pm 13$ & $171 \pm 13$ & $210 \pm 19$ \\
\hline \multicolumn{7}{|c|}{ Mean PAP (mmHG) } \\
\hline HTN & $68 \pm 2$ & $64 \pm 3$ & $59 \pm 3$ & $47 \pm 3^{*}$ & $56 \pm 5$ & $45 \pm 3^{*}$ \\
\hline BQ 123 & $69 \pm 4$ & $64 \pm 6$ & $55 \pm 5$ & $41 \pm 2$ & $54 \pm 4$ & $37 \pm 2$ \\
\hline \multicolumn{7}{|c|}{ Mean Pao $(\mathrm{mmHg})$} \\
\hline HTN & $47 \pm 2$ & $46 \pm 3^{*}$ & $45 \pm 3$ & $45 \pm 3$ & $43 \pm 6$ & $46 \pm 4$ \\
\hline BQ 123 & $44 \pm 4$ & $38 \pm 2$ & $40 \pm 2$ & $37 \pm 4$ & $42 \pm 4$ & $40 \pm 3$ \\
\hline \multicolumn{7}{|l|}{$\mathrm{pH}$, units } \\
\hline HTN & $7.18 \pm 0.07$ & $7.17 \pm 0.06$ & $7.29 \pm 0.02 *$ & $7.32 \pm 0.02$ & $7.31 \pm 0.04$ & $7.30 \pm 0.05^{*}$ \\
\hline BQ 123 & $7.22 \pm 0.04$ & $7.24 \pm 0.03$ & $7.36 \pm 0.02$ & $7.39 \pm 0.03$ & $7.37 \pm 0.06$ & $7.40 \pm 0.04$ \\
\hline \multicolumn{7}{|c|}{$\mathrm{PCO}_{2}(\mathrm{mmHg})$} \\
\hline HTN & $60 \pm 3$ & $62 \pm 4$ & $52 \pm 2 *$ & $36 \pm 3$ & $42 \pm 3$ & $45 \pm 5$ \\
\hline BQ 123 & $56 \pm 2$ & $55 \pm 2$ & $42 \pm 2$ & $44 \pm 2$ & $39 \pm 6$ & $36 \pm 4$ \\
\hline \multicolumn{7}{|c|}{$\mathrm{Po}_{2}(\mathrm{mmHg})$} \\
\hline HTN & $17 \pm 2$ & $18 \pm 2$ & $25 \pm 3$ & $75 \pm 23$ & $35 \pm 10 *$ & $38 \pm 10^{*}$ \\
\hline BQ 123 & $17 \pm 3$ & $17 \pm 1$ & $39 \pm 10$ & $66 \pm 16$ & $84 \pm 37$ & $99 \pm 37$ \\
\hline
\end{tabular}

Values are mean \pm SEM. Comparisons between HTN and BQ 123 values were made by repeated-measures ANOVA. * $=P<0.05$, HTN vs. BQ 123 . LPA, left pulmonary artery; PAP, pulmonary artery pressure; Pao, aortic pressure. 


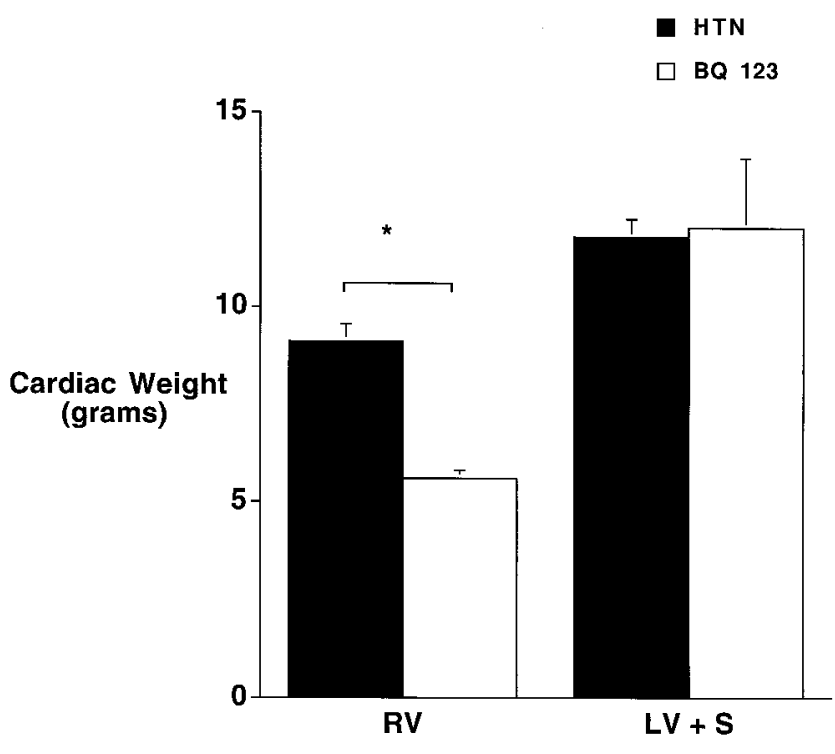

Figure 4. HTN vs. BQ 123. Effects of BQ 123 treatment on cardiac weight of the right ventricle $(R V)$ and left ventricle + septum $(L V+\mathrm{S})$. BQ $123(1.0 \mathrm{mg} /$ day $)$ blocked the increase in $\mathrm{RV}$ weight without changing the weight of the $\mathrm{LV}+\mathrm{S}$ in comparison with control $(H T N) . * P<0.05$.

BQ 123 treatment, suggesting that blockade of $\mathrm{ET}_{\mathrm{A}}$ receptor activity was sustained during treatment with $\mathrm{BQ} 123$.

Protocol 3: Hemodynamic effects of acute BQ 123 infusion after delivery. Acute infusion of BQ 123 in three HTN animals ventilated with $100 \% \mathrm{O}_{2}$ and inhaled NO lowered PVR from $0.41 \pm 0.11$ to $0.21 \pm 0.03 \mathrm{mmHg} / \mathrm{ml}$ per $\min (P<0.05)$ (Fig. 3$)$. PAP fell from $50 \pm 4$ to $35 \pm 2 \mathrm{mmHg}(P<0.05)$, but LPA flow did not change $(120 \pm 19$ vs. $142 \pm 16 \mathrm{ml} / \mathrm{min})$. Baseline values for Pao $(45 \pm 3 \mathrm{mmHg})$, Pla $(4 \pm 2 \mathrm{mmHg})$, heart rate $(170 \pm 7$ beats per $\mathrm{min}), \mathrm{pH}(7.32 \pm 0.03), \mathrm{PCO}_{2}(46 \pm 2 \mathrm{mmHg}), \mathrm{PO}_{2}$ $(36 \pm 8 \mathrm{mmHg})$, and hemoglobin $(6.9 \pm 0.4 \mathrm{~g} / \mathrm{dl})$ did not change during the infusion.

Protocol 4: Assessment of cardiac hypertrophy. BQ 123 blocked the development of right ventricular hypertrophy as the ratio of right ventricular weight to left ventricular + septum weight was lower with BQ 123 treatment $(0.79 \pm 0.03$ vs. $0.57 \pm 0.06$, HTN vs. BQ 123, $P<0.05)$. The left ventricle + septum weight did not change with BQ 123 treatment, but the weight of the right ventricle was lower in the BQ 123 group (Fig. 4). In comparison with previously published data in age-matched control animals without ductus arteriosus ligation (13), assessment of RVH was similar between BQ 123 treated animals and normal animals.

Protocol 5: Morphometric evaluation of the effect of prolonged $E T_{A}$ receptor blockade with $B Q 123$ on lung histology. BQ 123 treatment decreased wall thickness of small pulmonary arteries $(61 \pm 2 \%$ vs. $50 \pm 2 \%, \mathrm{HTN}$ vs. BQ $123, P<0.05)$ (Fig. 5). In the BQ 123 treated lungs, the\% WT was lower in the pulmonary arteries accompanying terminal and respiratory bronchioles, but not adjacent to alveolar ducts (Figs. 5 and 6).

\section{Discussion}

We report that chronic blockade of the $\mathrm{ET}_{\mathrm{A}}$ receptor with $\mathrm{BQ}$ 123 lowered fetal PAP, enhanced vasodilation at delivery, de-
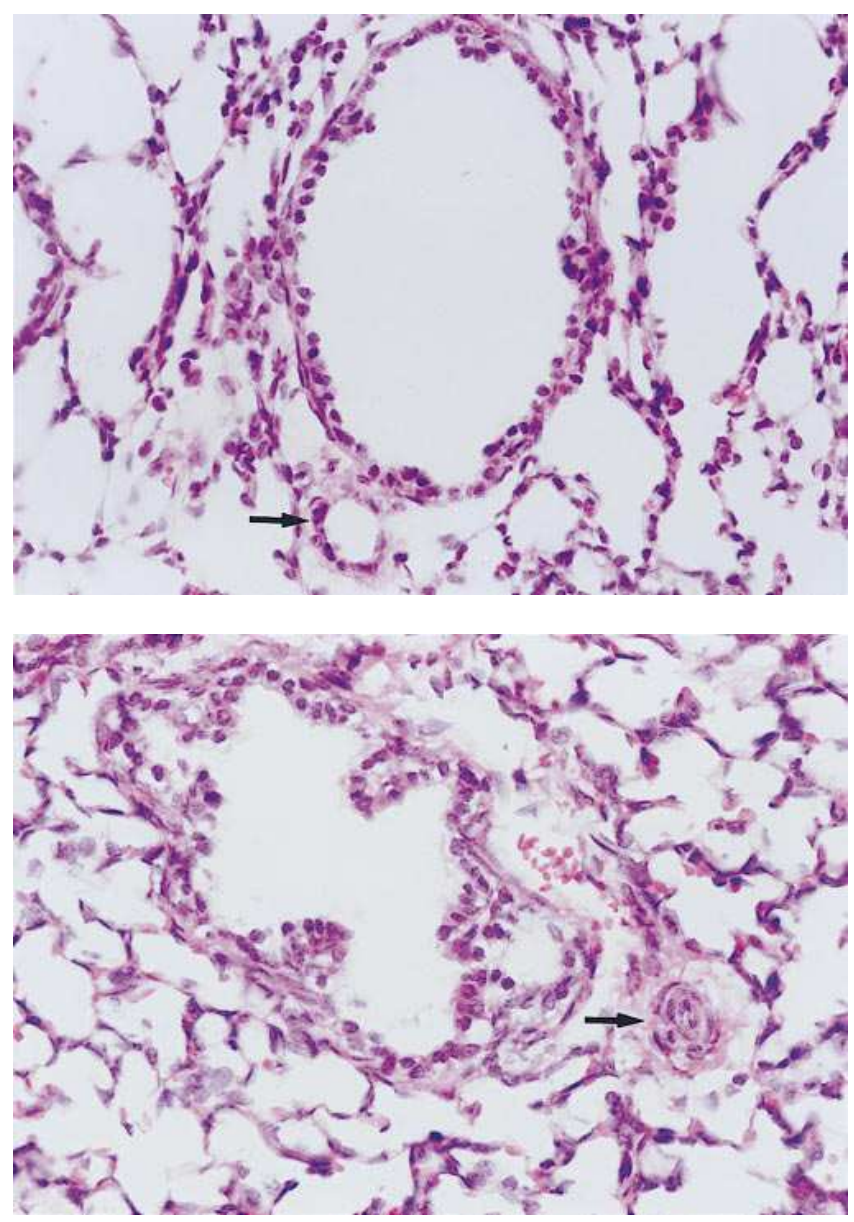

Figure 5. Effects of prolonged $\mathrm{ET}_{\mathrm{A}}$ receptor blockade with $\mathrm{BQ} 123$ on distal muscularization of small pulmonary arteries. BQ 123 (top) attenuated the medial hypertrophy of small pulmonary arteries $<100$ $\mu \mathrm{m}$ (arrow) adjacent to terminal bronchioles in comparison with hypertensive controls (bottom).

creased right ventricular hypertrophy, and decreased distal muscularization of small pulmonary arteries in the lung during the development of intrauterine pulmonary hypertension caused by ductus arteriosus ligation. In response to birthrelated stimuli, PVR fell to lower levels in lambs chronically treated with $\mathrm{BQ}$ 123. Furthermore, selective $\mathrm{ET}_{\mathrm{A}}$ receptor blockade acutely lowered PVR in control animals ventilated with $100 \% \mathrm{O}_{2}$ and inhaled $\mathrm{NO}$, demonstrating that $\mathrm{ET}_{\mathrm{A}}$-mediated vasoconstriction contributes to residual high tone even after rhythmic distension of the lung and vasodilation with $100 \%$ $\mathrm{O}_{2}$ and inhaled NO. These findings support the hypothesis that increased $\mathrm{ET}_{\mathrm{A}}$ receptor activity contributes to maintenance of high PVR in utero, failure of the normal transition at birth, right ventricular hypertrophy, and the structural changes in the pulmonary vascular bed during chronic fetal pulmonary hypertension.

Past studies of an experimental model of PPHN suggest that high PVR is partly due to structural changes and an imbalance in production and responsiveness to vasodilator and vasoconstrictor stimuli (2-6). Endothelium-dependent vasodilation and endogenous NO activity are impaired in the hypertensive fetal lung, whereas vasodilation to the cGMP agonists atrial 


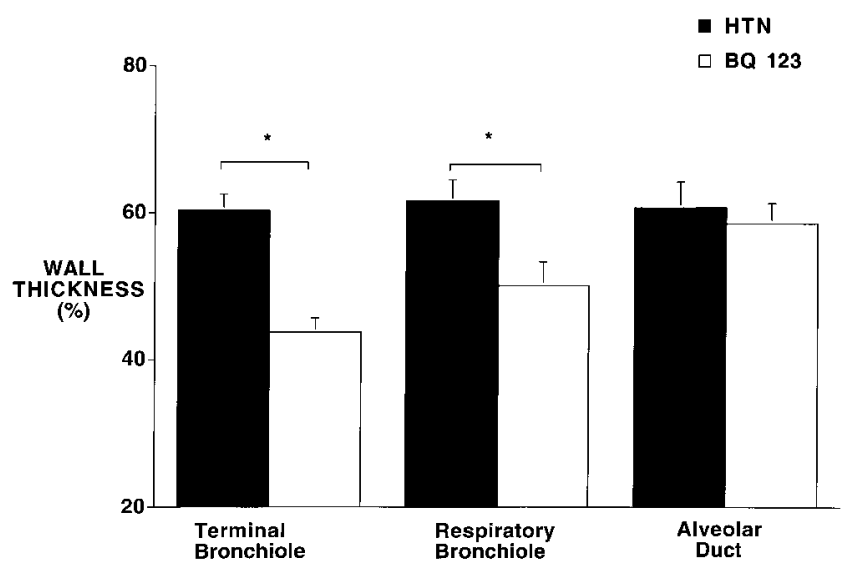

Figure 6. HTN vs. BQ 123. Effects of BQ 123 treatment on distal muscularization of small pulmonary arteries. In the BQ 123 treated lungs, the \% wall thickness $(T)$ was decreased in the pulmonary arteries accompanying terminal and respiratory bronchioles, but not adjacent to alveolar ducts in comparison with control hypertensive lungs $(H T N) . * P<0.05$.

natriuretic peptide and inhaled NO remain intact (6). Several studies suggest that ET-1 may contribute to vasoconstriction and altered vasoreactivity in experimental PPHN (12, 17-20). Diminished nitric oxide production and altered smooth muscle cell responsiveness are known to contribute to pulmonary hypertension $(6,21,22)$, and decreased NO production may increase ET-1 production (23). In addition to its effects on vascular tone, increased ET-1 activity also stimulates smooth muscle proliferation, which may further increase PVR (24).

Blockade of $\mathrm{ET}_{\mathrm{A}}$ receptor activity attenuates and reverses the development of pulmonary hypertension and right ventricular hypertrophy in adult rat models of pulmonary hypertension caused by chronic hypoxia or monocrotaline (25-29). Furthermore, studies of adult models of pulmonary hypertension demonstrate increased lung expression of $\mathrm{ET}_{\mathrm{A}}$ receptor mRNA (30) and decreased $\mathrm{ET}_{\mathrm{B}}$ receptor mRNA (31). Increased production of ET-1 has also been shown in adult rat pulmonary hypertension models $(31,32)$. We have previously shown that pulmonary hypertension due to ductus arteriosus ligation increases ET- 1 production threefold, and leads to diminished $\mathrm{ET}_{\mathrm{B}}$-mediated vasodilation and enhanced $\mathrm{ET}_{\mathrm{A}}$-mediated vasoconstriction, suggesting that increased ET-1 and changes in its receptor activity at least in part mediate the altered reactivity in this model of pulmonary hypertension (13). The present study significantly extends these observations, and demonstrates that chronic blockade of $\mathrm{ET}_{\mathrm{A}}$-mediated vasoconstriction attenuates perinatal pulmonary hypertension.

The physiologic role of ET-1 in the normal ovine fetal lung has been controversial. ET-1 is present in the perinatal lung (9), and is vasoactive in the fetus $(11,18,19,33,34)$. Brief infusion of ET-1 causes potent vasodilation acutely (17, 35-37), however, with prolonged infusion, hypertension prevails (18, 38). Exogenous infusion of ET-1, on the other hand, may not accurately describe the hemodynamic effects of endogenous production of ET-1 in the fetal lung. Evidence suggests that ET-1 acts as a local autocrine and paracrine factor rather than a circulating hormone, since secretion of ET-1 by endothelial cells is polar and directed abluminally toward the interstitial region (39). Some studies of exogenous infusion of ET-1 have emphasized that the major effect of ET-1 in the normal late gestation fetal lung is vasodilation, and that the majority of ET-1 receptors active in the ovine fetal lung are the $\mathrm{ET}_{\mathrm{B} 1}$ receptors $(17,37)$ which mediate only vasodilation $(11)$. In contrast, several studies suggest that the $\mathrm{ET}_{\mathrm{A}}$ receptors play an important role in mediating vasoconstriction in the late gestation ovine fetus $(11,20,33,40)$. Intrapulmonary infusion of big-ET-1, the precursor to ET-1, causes progressive and sustained pulmonary hypertension without even transient vasodilation (11, 19), suggesting that stimulation of endogenous ET-1 may have very different effects than brief exogenous infusions of ET-1. Blockade of the $\mathrm{ET}_{\mathrm{A}}$ receptors causes vasodilation $(11,37)$, whereas selective blockade of the $\mathrm{ET}_{\mathrm{B} 1}$ (vasodilation) or $\mathrm{ET}_{\mathrm{B} 2}$ (vasoconstriction) receptors does not change basal pulmonary tone in the ovine fetus (13). Brief and prolonged stimulation of the $\mathrm{ET}_{\mathrm{B}}$ receptors with sarafotoxin $\mathrm{S} 6 \mathrm{c}$, however, causes only vasodilation in the ovine fetal lung, suggesting the presence of only $\mathrm{ET}_{\mathrm{B} 1}$ receptors (11). In contrast, studies in newborn piglets suggest the presence of both $\mathrm{ET}_{\mathrm{B} 1}$ (vasodilation) and $\mathrm{ET}_{\mathrm{B} 2}$ (vasoconstriction) receptors in the neonatal lung (41). Therefore, it appears that the primary role of ET- 1 in the normal late-gestation ovine fetal lung is vasoconstriction. Recent studies have shown that combined $\mathrm{ET}_{\mathrm{A}}$ and $\mathrm{ET}_{\mathrm{B}}$ receptor blockade with Ro 47-0203 does not change the increase in pulmonary blood flow or decrease in pulmonary vascular resistance with in utero oxygen ventilation, suggesting that endogenous ET-1 activity does not play a major role in the increased pulmonary blood flow during the normal transitional circulation at birth (42).

This study has shown diminished right ventricular hypertrophy with chronic $\mathrm{ET}_{\mathrm{A}}$ receptor blockade, with increased pulmonary artery pressure and ductus arteriosus ligation. Whether this blockade of right ventricular hypertrophy to normal levels in the perinatal fetus is due to a direct effect on the right ventricle or to decreased pulmonary artery pressure is not known. The role of ET-1 in the development of cardiac ventricular hypertrophy is under active investigation. Cultured rat neonatal ventricular cardiomyocytes express a low level of ET-1 mRNA in the unstimulated state, but ET-1 mRNA expression increases in response to the alpha adrenergic agonist phenylephrine (43). Catecholamines increase expression of ET-1 mRNA by cultured ventricular myocytes in vitro and in vivo $(43,44)$, and exogenous ET-1 induces hypertrophy of cultured myocytes (45). Increased pressure load to the myocardium also increases ET-1 mRNA expression $(46,47)$. The $\mathrm{ET}_{\mathrm{A}}$ receptor mediates the hypertrophic effects of ET-1 on cultured adult (48) and neonatal (49) ventricular myocytes. Although adult myocytes do not express $\mathrm{ET}_{\mathrm{B}}$ receptors (48), angiotensin-II may increase expression of $\mathrm{ET}_{\mathrm{B}}$ receptors in neonatal rat cardiomyocytes $(50)$.

The present study demonstrates improved hemodynamics with acute and chronic $\mathrm{ET}_{\mathrm{A}}$ receptor blockade after ductus arteriosus ligation. Chronic BQ 123 infusion attenuated the in utero increase in PAP, blocked right ventricular hypertrophy $(\mathrm{RVH})$, attenuated distal muscularization of small pulmonary arteries, and improved vasodilation after delivery. Acute infusion of BQ 123 in control animals lowered PVR levels similar to those shown with chronic BQ 123 treatment during mechanical ventilation and vasodilation with $100 \% \mathrm{O}_{2}$ and inhaled NO. Thus, $\mathrm{ET}_{\mathrm{A}}$-mediated vasoconstriction contributes to residual high tone, even after rhythmic distension and vasodilation with $100 \% \mathrm{O}_{2}$ and inhaled NO. This fact further suggests 
that acute treatment with BQ 123 may be as effective as chronic intrauterine blockade of the $\mathrm{ET}_{\mathrm{A}}$ receptor in this model of perinatal pulmonary hypertension. Blockade of $\mathrm{ET}_{\mathrm{A}}$ receptor activity was sustained during infusion of $\mathrm{BQ} 123$ since infusion of big-endothelin-1, a selective $\mathrm{ET}_{\mathrm{A}}$ receptor agonist, did not change pulmonary tone in animals treated with prolonged BQ 123 treatment. We speculate, therefore, that $\mathrm{ET}_{\mathrm{A}}$ receptor blockade may provide treatment for disease states characterized by chronic intrauterine pulmonary hypertension, such as PPHN.

ET-1 levels are increased in many human disorders of pulmonary hypertension. Elevated immunoreactive ET-1 levels have been found in primary pulmonary hypertension, the Eisenmenger syndrome (51), PPHN (52), children with pulmonary hypertension associated with congenital heart disease and bronchopulmonary dysplasia (53), and children with congenital heart disease and increased pulmonary blood flow $(54,55)$. Increased expression of ET-1 in vascular endothelial cells has been reported in adult patients with primary pulmonary hypertension, suggesting that the local production of endothelin-1 may contribute to the altered vascular reactivity and structural changes seen in pulmonary hypertension (56). Recently, acute infusion of the combined $\mathrm{ET}_{\mathrm{A}}$ and $\mathrm{ET}_{\mathrm{B}}$ receptor antagonist bosentan has been shown to lower PVR and increase cardiac output in congestive heart failure and pulmonary hypertension (57). However, the role of ET-1 in clinical disorders of perinatal pulmonary hypertension (such as PPHN) remains incompletely understood.

In summary, chronic blockade of the $\mathrm{ET}_{\mathrm{A}}$ receptor with BQ 123 lowered fetal PAP, enhanced vasodilation at delivery, decreased right ventricular hypertrophy, and decreased distal muscularization of small pulmonary arteries in the lung during the development of intrauterine pulmonary hypertension by ductus arteriosus ligation. Selective $\mathrm{ET}_{\mathrm{A}}$ receptor blockade acutely lowered PVR in control animals ventilated with $100 \%$ $\mathrm{O}_{2}$ and inhaled $\mathrm{NO}$, demonstrating that $\mathrm{ET}_{\mathrm{A}}$-mediated vasoconstriction contributes to residual high tone, even after rhythmic distension and vasodilation with $100 \% \mathrm{O}_{2}$ and inhaled NO. These findings support the hypothesis that increased $\mathrm{ET}_{\mathrm{A}}$ receptor activity contributes to maintenance of high PVR in utero, failure of the normal transition at birth, right ventricular hypertrophy, and structural changes in the pulmonary vascular bed during chronic fetal pulmonary hypertension. We speculate that $\mathrm{ET}_{\mathrm{A}}$ receptor blockade may provide treatment for disease states characterized by chronic intrauterine pulmonary hypertension.

\section{Acknowledgments}

This work was supported in part by grants from the National Institutes of Health (H241012 and 46481, S.H. Abman), the March of Dimes Birth Defects Foundation (D. Dunbar Ivy and John P. Kinsella), the Bugher Physician-Scientist Training Program (D. Dunbar Ivy and J.P. Kinsella), the Children's Hospital Research Institute (D. Dunbar Ivy), and the American Heart Association Established Investigator Award (S.H. Abman).

\section{References}

1. Levin, D.L., M.A. Heymann, J.A. Kitterman, G.A. Gregory, R.H. Phibbs, and A.M. Rudolph. 1976. Persistent pulmonary hypertension of the newborn infant. J. Pediatr. 89:626-630.

2. Abman, S.H., P.F. Shanley, and F.J. Accurso. 1989. Failure of postnatal adaptation of the pulmonary circulation after chronic intrauterine pulmonary hypertension in fetal lambs. J. Clin. Invest. 83:1849-1858.

3. Morin, F.C. 1989. Ligating the ductus arteriosus before birth causes persistent pulmonary hypertension in the newborn lamb. Pediatr. Res. 25:245-250.

4. Murphy, J.D., M. Rabinovitch, J.D. Goldstein, and L.M. Reid. 1981. The structural basis of persistent pulmonary hypertension of the newborn infant. $J$. Pediatr. 98:962-967.

5. Belik, J., A.J. Halayko, K. Rao, and N.L. Stephens. 1993. Fetal ductus arteriosus ligation. Pulmonary vascular smooth muscle biochemical and mechanical changes. Circ. Res. 72:588-596.

6. McQueston, J.A., J.P. Kinsella, D.D. Ivy, I.F. McMurtry, and S.H. Abman. 1995. Chronic pulmonary hypertension in utero impairs endotheliumdependent vasodilation. Am. J. Physiol. 268:288-294.

7. Yanagisawa, M., H. Kurihara, S. Kimura, Y. Tomobe, M. Kobayashi, Y Mitsui, Y. Yazaki, K. Goto, and T. Masaki. 1988. A novel potent vasoconstrictor peptide produced by vascular endothelial cells. Nature (Lond.). 332:411415

8. Coceani, F., and L. Kelsey. 1991. Endothelin-1 release from lamb ductus arteriosus: relevance to postnatal closure of the vessel. Can. J. Physiol. Pharmacol. 69:218-221.

9. MacCumber, M.W., C.A. Ross, B.M. Glaser, and S.H. Snyder. 1989. Endothelin: visualization of mRNAs by in situ hybridization provides evidence for local action. Proc. Natl. Acad. Sci. USA. 86:7285-7289.

10. Nakamura, T., K. Kasai, S. Konuma, T. Emoto, N. Banba, M. Ishikawa, and S. Shimoda. 1990. Immunoreactive endothelin concentrations in maternal and fetal blood. Life Sci. 46:1045-1050.

11. Ivy, D.D., J.P. Kinsella, and S.H. Abman. 1994. Physiologic characterization of endothelin A and B receptor activity in the ovine fetal pulmonary circulation. J. Clin. Invest. 93:2141-2148.

12. Wang, Y., and F. Coceani. 1992. Isolated pulmonary resistance vessels from fetal lambs. Contractile behavior and responses to indomethacin and endothelin-1. Circ Res. 71:320-330.

13. Ivy, D.D., J.W. Ziegler, M.F. Dubus, J.J. Fox, J.P. Kinsella, and S.H Abman. 1996. Chronic intrauterine pulmonary hypertension alters endothelin receptor activity in the ovine fetal lung. Pediatr. Res. 39:435-442.

14. Abman, S.H., R.B. Wilkening, R.M. Ward, and F.J. Accurso. 1986. Adaptation of fetal pulmonary blood flow to local infusion of tolazoline. Pediatr. Res. 20:1131-1135.

15. Lewis, A.B., M.A. Heymann, and A.M. Rudolph. 1976. Gestational changes in pulmonary vascular responses in fetal lambs in utero. Circ. Res. 39: 536-541.

16. Lock, J.E., F. Hamilton, H. Luide, F. Coceani, and P.M. Olley. 1980. Direct pulmonary vascular responses in the conscious newborn lamb. J. Appl. Physiol. 48:188-196.

17. Cassin, S., V. Kristova, T. Davis, P. Kadowitz, and G. Gause. 1991 Tone-dependent responses to endothelin in the isolated perfused fetal sheep pulmonary circulation in situ. J. Appl. Physiol. 70:1228-1234.

18. Chatfield, B.A., I.F. McMurtry, S.L. Hall, and S.H. Abman. 1991. Hemodynamic effects of endothelin-1 on ovine fetal pulmonary circulation. Am. J. Physiol. 261:182-187.

19. Jones, O.W., and S.H. Abman. 1994. Systemic and pulmonary hemodynamic effects of big endothelin-1 and phosphoramidon in the ovine fetus. Am. J. Physiol. 266:929-955.

20. Wang, Y., Y. Coe, O. Toyoda, and F. Coceani. 1995. Involvement of endothelin-1 in hypoxic pulmonary vasoconstriction in the lamb. J. Phys. (Lond.) 482:421-434.

21. Cornfield, D.N., B.A. Chatfield, J.A. McQueston, I.F. McMurtry, and S.H. Abman. 1992. Effects of birth-related stimuli on L-arginine-dependent pulmonary vasodilation in ovine fetus. Am. J. Physiol. 262:1474-1481.

22. Abman, S.H., B.A. Chatfield, S.L. Hall, and I.F. McMurtry. 1990. Role of endothelium-derived relaxing factor during transition of pulmonary circulation at birth. Am. J. Physiol. 259:1921-1927.

23. Kourembanas, S., L.P. McQuillan, G.K. Leung, and D.V. Faller. 1993. Nitric oxide regulates the expression of vasoconstrictors and growth factors by vascular endothelium under both normoxia and hypoxia. J. Clin. Invest. 92:99104

24. Zamora, M.A., E.C. Dempsey, S.J. Walchak, and T.J. Stelzner. 1993 $\mathrm{BQ123}$, an $\mathrm{ET}_{\mathrm{A}}$ receptor antagonist, inhibits endothelin-1-mediated proliferation of human pulmonary artery smooth muscle cells. Am. J. Respir. Cell Mol. Biol. 9:429-433.

25. Bonvallet, S.T., M.R. Zamora, K. Hasunuma, K. Sato, N. Hanasato, D. Anderson, K. Sato, and T.J. Stelzner. 1994. BQ123, an ET $_{\mathrm{A}}$-receptor antagonist, attenuates hypoxic pulmonary hypertension in rats. Am. J. Physiol. 266: 1327-1331.

26. Miyauchi, T., R. Yorikane, S. Sakai, T. Sakurai, M. Okada, M. Nishikibe, M. Yano, I. Yamaguchi, Y. Sugishita, and K. Goto. 1993. Contribution of endogenous endothelin-1 to the progression of cardiopulmonary alterations in rats with monocrotaline-induced pulmonary hypertension. Circ. Res. 73:887897

27. Eddahibi, S., B. Raffestin, P. Braquet, P.E. Chabrier, and S. Adnot. 1991. Pulmonary vascular reactivity to endothelin-1 in normal and chronically pulmonary hypertensive rats. J. Cardiovasc. Pharmacol. 17 (Suppl.) 7:358-361. 
28. Chen, S.J., Y.F. Chen, Q.C. Meng, J. Durand, V.S. DiCarlo, and S. Oparil. 1995. Endothelin-receptor antagonist bosentan prevents and reverses hypoxic pulmonary hypertension in rats. J. Appl. Physiol. 79:2122-2131.

29. DiCarlo, V.S., S.J. Chen, Q.C. Meng, J. Durand, M. Yano, Y.F. Chen, and S. Oparil. 1995. $\mathrm{ET}_{\mathrm{A}}$-receptor antagonist prevents and reverses chronic hypoxia-induced pulmonary hypertension in rat. Am. J. Physiol. 269:690-697.

30. Li, H., T.S. Elton, Y.F. Chen, and S. Oparil. 1994. Increased endothelin receptor gene expression in hypoxic rat lung. Am. J. Physiol. 266:553-560.

31. Yorikane, R., T. Miyauchi, S. Sakai, T. Sakurai, I. Yamaguchi, Y. Sugishita, and K. Goto. 1993. Altered expression of ETB-receptor mRNA in the lung of rats with pulmonary hypertension. J. Cardiovasc. Pharmacol. 22 (Suppl.) 8:336-338.

32. Stelzner, T.J., R.F. O'Brien, M. Yanagisawa, T. Sakurai, K. Sato, S. Webb, M. Zamora, I.F. McMurtry, and J.H. Fisher. 1992. Increased lung endothelin-1 production in rats with idiopathic pulmonary hypertension. Am. J. Physiol. 262:614-620.

33. Ivy, D.D., J.P. Kinsella, and S.H. Abman. 1996. Endothelin blockade augments pulmonary vasodilation in the ovine fetus. J. Appl. Physiol. 81:24812487.

34. Tod, M.L., and S. Cassin. 1992. Endothelin-1-induced pulmonary arterial dilation is reduced by $\mathrm{N}$ omega-nitro-L-arginine in fetal lambs. J. Appl. Physiol. 72:1730-1734.

35. Lippton, H.L., G.A. Cohen, I.F. McMurtry, and A.L. Hyman. 1991. Pulmonary vasodilation to endothelin isopeptides in vivo is mediated by potassium channel activation. J. Appli. Physiol. 70:947-952.

36. Wong, J., P.A. Vanderford, J.R. Fineman, R. Chang, and S.J. Soifer. 1993. Endothelin-1 produces pulmonary vasodilation in the intact newborn lamb. Am. J. Physiol. 265:1318-1325.

37. Wong, J., J.R. Fineman, and M.A. Heymann. 1994. The role of endothelin and endothelin receptor subtypes in regulation of fetal pulmonary vascular tone. Pediatr. Res. 35:664-670.

38. Liben, S., D.J. Stewart, J. De Marte, and T. Perreault. 1993. Ontogeny of Big endothelin-1 effects in newborn piglet pulmonary vasculature. Am. J. Physiol. 265:139-145.

39. Wagner, O.F., G. Christ, J. Wojta, H. Vierhapper, S. Parzer, P.J. Nowotny, B. Schneider, W. Waldhausl, and B.R. Binder. 1992. Polar secretion of endothelin-1 by cultured endothelial cells. J. Biol. Chem. 267:16066-16068.

40. Wang, Y., and F. Coceani. 1992. Isolated pulmonary resistance vessels from fetal lambs. Contractile behavior and responses to indomethacin and endothelin-1. Circ. Res. 71:320-330.

41. Perreault, T., and J. Baribeau. 1995. Characterization of endothelin receptors in newborn piglet lung. Am. J. Physiol. 268:607-614.

42. Winters, J.W., J. Wong, D. Van Dyke, M. Johengen, M.A. Heymann, and J.R. Fineman. 1996. Endothelin receptor blockade does not alter the increase in pulmonary blood flow due to oxygen ventilation in fetal lambs. Pediatr. Res. 40:152-157.

43. Kaddoura, S., J.D. Firth, S.J. Fuller, P.A. Poole-Wilson, and P.H. Sugden. 1995. Ventricular myocytes in culture express endothelin-1 but not ET-2 or ET-3 mRNA in response to the hypertrophic agonists phenylephrine and ET-1. J. Am. Coll. Cardiol. 415A.
44. Kaddoura, S., J.D. Firth, K.R. Boheler, P.H. Sugden, and P.A. PooleWilson. 1996. Endothelin-1 is involved in norepinephrine-induced ventricular hypertrophy in vivo. Circulation. 93:2068-2079.

45. Ito, H., Y. Hirata, M. Hiroe, M. Tsujino, S. Adachi, T. Takamoto, M. Nitta, K. Taniguchi, and F. Marumo. 1991. Endothelin-1 induces hypertrophy with enhanced expression of muscle-specific genes in cultured neonatal rat cardiomyocytes. Circ. Res. 69:209-215.

46. Ito, H., M. Hiroe, Y. Hirata, H. Fujisaki, S. Adachi, H. Akimoto, Y. Ohta, and F. Marumo. 1994. Endothelin $\mathrm{ET}_{\mathrm{A}}$ receptor antagonist blocks cardiac hypertrophy provoked by hemodynamic overload. Circulation. 89:21982203.

47. Arai, M., A. Yoguchi, T. Iso, T. Takahashi, S. Imai, K. Murata, and T. Suzuki. 1995. Endothelin-1 and its binding sites are upregulated in pressure overload cardiac hypertrophy. Am. J. Physiol. 268:2084-2091.

48. Hilal-Dandan, R., D.T. Merck, J.P. Lujan, and L.L. Brunton. 1994. Coupling of the type A endothelin receptor to multiple responses in adult rat cardiac myocytes. Mol. Pharmacol. 45:1183-1190.

49. Ito, H., Y. Hirata, S. Adachi, M. Tanaka, M. Tsujino, A. Koike, A. Nogami, F. Murumo, and M. Hiroe. 1993. Endothelin-1 is an autocrine/paracrine factor in the mechanism of angiotensin II-induced hypertrophy in cultured rat cardiomyocytes. J. Clin. Invest. 92:398-403.

50. Kanno, K., Y. Hirata, M. Tsujino, T. Imai, M. Shichiri, H. Ito, and F. Marumo. 1993. Up-regulation of ETB receptor subtype mRNA by angiotensin-II in rat cardiomyocytes. Biochem. Biophys. Res. Commun. 194:1282-1287.

51. Cacoub, P., R. Dorent, G. Maistre, P. Nataf, A. Carayon, C. Piette, P. Godeau, C. Cabrol, and I. Gandjbakhch. 1993. Endothelin-1 in primary pulmonary hypertension and the Eisenmenger syndrome. Am. J. Cardiol. 71:448-450.

52. Rosenberg, A.A., J. Kennaugh, S.L. Koppenhafer, M. Loomis, B.A. Chatfield, and S.H. Abman. 1993. Elevated immunoreactive endothelin-1 levels in newborn infants with persistent pulmonary hypertension. J. Pediatr. 123:109114

53. Allen, S.W., B.A. Chatfield, S.A. Koppenhafer, M.S. Schaffer, R.R. Wolfe, and S.H. Abman. 1993. Circulating immunoreactive endothelin-1 in children with pulmonary hypertension. Association with acute hypoxic pulmonary vasoreactivity. Am. Rev. Respir. Dis. 148:519-522.

54. Komai, H., I.T. Adatia, M.J. Elliott, M.R. de Leval, and S.G. Haworth 1993. Increased plasma levels of endothelin-1 after cardiopulmonary bypass in patients with pulmonary hypertension and congenital heart disease. J. Thorac. Cardiovasc. Surg. 106:473-478.

55. Vincent, J.A., R.D. Ross, J. Kassab, J.M. Hsu, and W.W. Pinsky. 1993. Relation of elevated plasma endothelin in congenital heart disease to increased pulmonary blood flow. Am. J. Cardiol. 71:1204-1207.

56. Giaid, A., M. Yanagisawa, D. Langleben, R.P. Michel, R. Levy, H Shennib, S. Kimura, T. Masaki, W.P. Duguid, and D.J. Stewart. 1993. Expression of endothelin-1 in the lungs of patients with pulmonary hypertension. $N$. Engl. J. Med. 328:1732-1739.

57. Kiowski, W., G. Sutsch, P. Hunziker, P. Muller, J. Kim, E. Oechslin, R Schmitt, R. Jones, and O. Bertel. 1995. Evidence for endothelin-1-mediated vasoconstriction in severe chronic heart failure. Lancet. 346:732-736. 